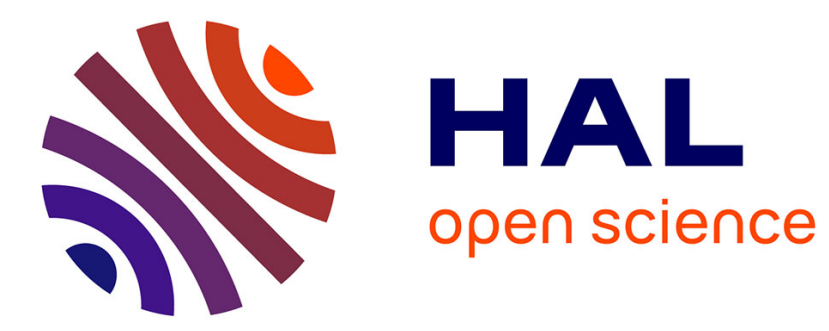

\title{
Afforestation with Eucalyptus globulus and leaf litter decomposition in streams of northern Spain
}

Jesús Pozo, Ana Basaguren, Arturo Elosegui, Jon Molinero, Eric Fabre, Eric

Chauvet

\section{- To cite this version:}

Jesús Pozo, Ana Basaguren, Arturo Elosegui, Jon Molinero, Eric Fabre, et al.. Afforestation with Eucalyptus globulus and leaf litter decomposition in streams of northern Spain. Hydrobiologia, 1998, vol. 373/374, pp. 101-110. hal-00956309

\section{HAL Id: hal-00956309 \\ https://hal.science/hal-00956309}

Submitted on 6 Mar 2014

HAL is a multi-disciplinary open access archive for the deposit and dissemination of scientific research documents, whether they are published or not. The documents may come from teaching and research institutions in France or abroad, or from public or private research centers.
L'archive ouverte pluridisciplinaire HAL, est destinée au dépôt et à la diffusion de documents scientifiques de niveau recherche, publiés ou non, émanant des établissements d'enseignement et de recherche français ou étrangers, des laboratoires publics ou privés. 


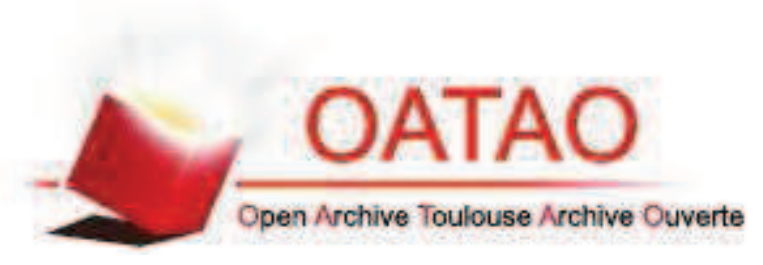

\section{Open Archive TOULOUSE Archive Ouverte (OATAO)}

OATAO is an open access repository that collects the work of Toulouse researchers and makes it freely available over the web where possible.

This is an author-deposited version published in : http://oatao.univ-toulouse.fr/ Eprints ID : 9662

To link to this article : DOI : 1023/A:1017038701380

URL : http://link.springer.com/article/10.1023\%2FA\%3A1017038701380

To cite this version : Pozo, Jesús and Basaguren, Ana and Elosegui, Arturo and Molinero, Jon and Fabre, Eric and Chauvet, Eric Afforestation with Eucalyptus globulus and leaf litter decomposition in streams of northern Spain. (1998) Hydrobiologia: The International Journal of Aquatic Sciences, vol. 373/374 (n 0). pp. 101-110. ISSN $\underline{0018-8158}$

Any correspondance concerning this service should be sent to the repository administrator: staff-oatao@,listes-diff.inp-toulouse.fr 


\title{
Afforestation with Eucalyptus globulus and leaf litter decomposition in streams of northern Spain
}

\author{
J. Pozo ${ }^{1}$, A. Basaguren ${ }^{1}$, A. Elósegui ${ }^{1}$, J. Molinero ${ }^{1}$, E. Fabre ${ }^{2}$ \& E. Chauvet ${ }^{2}$ \\ ${ }^{1}$ Lab. Ecología, Fac. Ciencias, Universidad del País Vasco/Euskal Herriko Unibertsitatea, Apdo. 644, 48080 \\ Bilbao, Spain \\ ${ }^{2}$ Centre d'Ecologie des Systèmes Aquatiques Continentaux (CNRS-UPS). 29, rue Jeanne Marvig, 31055 Toulouse \\ Cedex 04, France
}

Key words: Afforestation, eucalyptus, stream, litter breakdown, fungi, macroinvertebrates, nutrients

\begin{abstract}
To test the hypothesis that decomposition of leaf species in streams is influenced by afforestation with Eucalyptus globulus, we compared decay rates, nutrient levels, fungal biomass and macroinvertebrate assemblages on alder and eucalyptus leaf litter in three streams (two headwaters under different forests, and a mid reach) of the Agüera catchment (northern Spain).

Whatever the reach, alder always decomposed significantly faster than eucalyptus. Litter contents in nitrogen and phosphorus rose during breakdown at the mid reach, but not at the headwaters. No differences in fungal biomass were found between alder and eucalyptus leaves at the headwater reaches; however, at the mid reach, eucalyptus showed the highest values.

Alder litter, a high quality substratum, was readily colonized by shredders, and decayed rapidly at all sites. Eucalyptus, a low quality species, had lower nutrient contents and was less favoured by shredders. Under high nutrient levels (particularly phosphorus), however, it was readily colonized by fungi, thus shifting from medium to high breakdown rates. The potentially negative impact of afforestation with eucalyptus on streams can thus be reduced in situations of high concentrations of dissolved nutrients.
\end{abstract}

\section{Introduction}

Litter of terrestrial origin is the main trophic resource for the communities of many headwater streams (Petersen \& Cummins, 1974; Vannote et al., 1980). Disturbance of the vegetation can affect the amount and quality of litter entering the stream (Golladay et al., 1989; Webster et al., 1990), and thus, may have substantial impacts on the functioning of stream systems.

There is an extensive literature on the effects of clearcutting on streams (Meyer \& Jonhson, 1983; Griffith \& Perry, 1991; Campbell et al., 1992; Tuchman \& King, 1993; David et al, 1994), but the large-scale substitution of tree species can also have important effects (Griffith \& Perry, 1991; Pozo et al., 1997), although these have not been thoroughly studied.

The large-scale plantation of eucalyptus outside its natural range has created some concern among limnologists (Graça, 1993; Bärlocher et al., 1995). Eucalyptus litter has frequently been quoted as of low quality and slow breakdown rate (Bunn, 1988a; Boulton, 1991), characteristics which are linked to its high content of phenolics and tannins, and to its waxy cuticles (Bunn, 1988a; Campbell et al., 1992; Bärlocher et al., 1995). However, the genus has hundreds of species growing in a wide variety of climatic and edaphic conditions, and showing broad differences in litter texture and composition (Mitchell, 1988).

Eucalyptus globulus Labill is one of the most widespread planted eucalyptus in the North of Spain (ICONA, 1980). Recent work by Abelho \& Graça 
(1996) in Portugal suggests that afforestation with this species can affect the breakdown rates of different leaf species (e.g., eucalyptus and chestnut). Some attempts to elucidate its impact on streams have addressed litter decomposition in the Agüera catchment (northern Spain). The first of these studies suggested that breakdown of low quality leaves such as eucalyptus was mainly influenced by concentrations of dissolved nitrogen and phosphorus (Pozo, 1993). In the headwaters, macroinvertebrates preferred alder over eucalyptus litter, suggesting that shredding activity could be responsible for the difference in decay rate between both species in nutrient-poor waters (Basaguren \& Pozo, 1994). Later results (Molinero et al., 1996) confirmed that the loss rate of eucalyptus mass depended on the external nutrient supply (dissolved nutrients in stream water), and not on the type of riparian vegetation (deciduous forest versus eucalyptus plantation). Nutrient enrichment of materials during decomposition suggested that microbial activity is site-dependent and related to the nutrient concentration in water. Chauvet et al. (1997) showed that, whatever the stream, neither total conidial production nor number of hyphomycete species were different between eucalyptus and alder litter. Furthermore, at a site richer in phosphate, conidial production increased to the same extent in both types of leaves.

The present work addresses the breakdown of alder and eucalyptus litter in streams in relation to the riparian environment, nutrient availability, leaf quality, and colonization by fungi and macroinvertebrates.

\section{Study sites}

The Agüera is a third order stream in northern Spain, draining a catchment of $144 \mathrm{~km}^{2}$. The uplands are covered by indigenous deciduous forests in the headwaters of the main channel, and by pine and eucalyptus plantations in the others; the lowlands are occupied by meadows and crops. The climate is temperate oceanic, with rainfall around $1500 \mathrm{~mm} \mathrm{yr}^{-1}$, and mean monthly temperatures ranging from $8{ }^{\circ} \mathrm{C}$ to $21^{\circ} \mathrm{C}$.

This work was carried out in three stream reaches: site A is located in the Salderrey stream, a first-order tributary surrounded by mature deciduous forest with oak, chestnut, alder and hazel; site $\mathrm{C}$ is in an unnamed first-order stream flowing through a plantation of $E u$ calyptus globulus; site B is in a third-order reach of the Agüera stream, surrounded by eucalyptus plantations but with riparian fringes of alder, sycamore and oak.
The water characteristics are similar in the two first-order reaches: low conductivity and phosphorus content (Table 1). Site B drains a more complex catchment, which includes some villages. As a result, the mineralization and the dissolved phosphate are higher, although the water quality is good (Elósegui et al., 1995).

\section{Methods}

On 15 November 1994, we filled a series of $5 \mathrm{~mm}$ mesh bags ( 4 replicates $\times 2$ species $\times 3$ sites $\times 6$ dates) with $15 \mathrm{~g}$ of freshly fallen leaves of either Alnus glutinosa or Eucalyptus globulus. They were stored overnight in a refrigerator, and placed randomly the next day, attached to boulders in the study sites. In total, 144 bags were filled, 72 of each leaf type. After $1,3,8,14,20$ and 26 weeks of immersion, four bags of each leaf species at each site were returned to the laboratory. Due to rapid breakdown, no alder material remained at site $\mathrm{A}$ after 14 weeks or at site $\mathrm{C}$ after 20 weeks. At site B, loss of bags forced termination of the experiment at week 8 (alder) or 14 (eucalyptus).

After collection, the contents of each bag were rinsed with distilled water on a $200 \mu \mathrm{m}$ sieve, the macroinvertebrates were collected and preserved in $70 \%$ ethanol, and the leaves enclosed in plastic bags and frozen to $-20{ }^{\circ} \mathrm{C}$.

Thereafter, the leaf material was lyophilized, weighed, and sorted in subsamples for the determination of ash (combustion), nitrogen (Kjeltec Auto 1030), phosphorus (Allen et al., 1974) and ergosterol (Gessner et al., 1991). The macroinvertebrates were sorted under a binocular microscope, identified mostly to the species or genus level, and assigned to functional feeding groups (e.g., Cummins \& Klug, 1979; Merritt \& Cummins, 1996).

Leaf mass loss was expressed as percentage of initial AFDW remaining. We calculated breakdown rates according to the negative exponential model (Petersen \& Cummins, 1974), by linear regression of lntransformed data. Analyses of covariance, with time as covariant, were used to compare slopes, and significant differences were determined using Tukey's test (Zar, 1984). Two way ANOVAs (time versus species and time versus site) and Tukey's tests were used to test differences in nutrient and ergosterol contents and macroinvertebrate densities. 
Table 1. Mean and range for selected physico-chemical characteristics of the water at the studied sites. (TIN = Total Inorganic Nitrogen)

\begin{tabular}{lccc}
\hline & Site A & Site B & Site C \\
\hline Temperature $\left({ }^{\circ} \mathrm{C}\right)$ & $8.8(5.7-12.4)$ & $10.9(9.0-14.8)$ & $10.5(7.7-13.7)$ \\
Conductivity $\left(\mu \mathrm{S} \mathrm{cm}^{-1}\right)$ & $99(84-120)$ & $206(104-260)$ & $64(56-72)$ \\
$\mathrm{pH}$ & $7.2(7.0-7.8)$ & $8.2(7.8-8.8)$ & $6.6(6.3-7.2)$ \\
$\mathrm{TIN}\left(\mu \mathrm{g} \mathrm{N}^{-1}\right)$ & $806(473-1493)$ & $642(373-1132)$ & $340(127-824)$ \\
Orthophosphate $\left(\mu \mathrm{g} \mathrm{P}^{-1}\right)$ & $3.8(2.7-7.5)$ & $10.3(3.0-25.2)$ & $3.2(2.1-5.0)$ \\
\hline
\end{tabular}

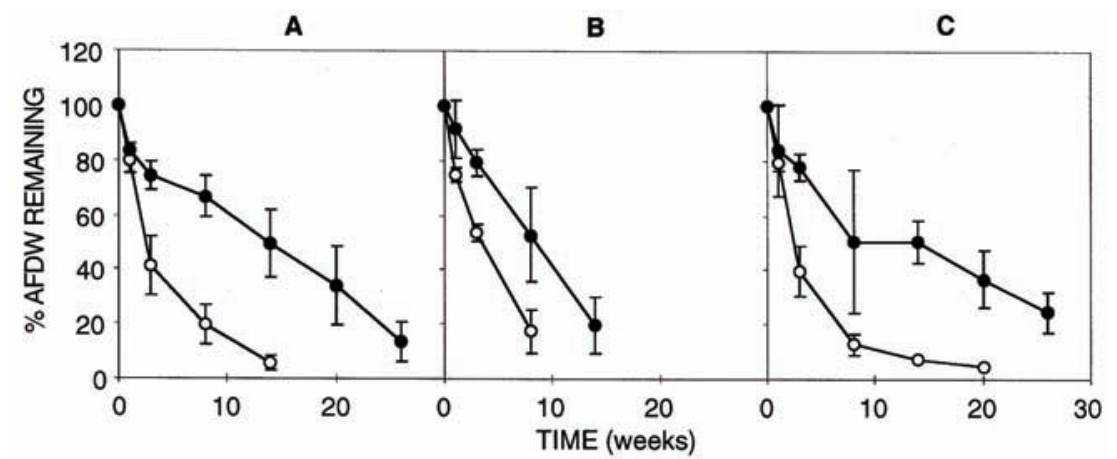

Figure 1. Breakdown dynamics (mean \pm S.D.) of alder $(\bigcirc)$ and eucalyptus $(\bullet)$ litter at the three studied sites.

\section{Results}

Mass loss

There were large differences in breakdown dynamics between leaf types (Figure 1). Mass loss of alder during the first week was very similar in all sites, and was slightly greater than that of eucalyptus. After this period, differences between species became evident: alder decayed much more rapidly than eucalyptus, with less than $10 \%$ of the initial mass remaining after 14 weeks.

Breakdown was most rapid at site B and slowest at site $\mathrm{C}$, although differences were significant only for eucalyptus (Table 2). Whatever the reach, alder always decayed at a significantly greater rate than eucalyptus ( $\mathrm{k}$ from 0.0235 to $0.0321 \mathrm{~d}^{-1}$ for alder, from 0.0066 to $0.0169 \mathrm{~d}^{-1}$ for eucalyptus).

\section{Nutrient content}

There were significant differences in the initial composition of litter: nitrogen contents of $2.84 \%$ and $0.92 \%$, and phosphorus contents of $0.080 \%$ and $0.035 \%$ were found in alder and eucalyptus respectively.

Figure 2 shows the changes in nitrogen and phosphorus contents of leaf litter over time. At site B, both species underwent nitrogen enrichment, but concentration was higher in alder, which resulted in increased differences between species. In headwater reaches, the $\mathrm{N}$ content in eucalyptus showed very small changes while in alder it increased sharply at site A during the first three weeks, and then fell to levels near the initial values; at site $\mathrm{C}$, the $\mathrm{N}$ content in alder increased during the first week, then decreased, and after the eighth week recovered its initial value.

The difference in nitrogen content between species was significant in all sites (Table 3), the values always being higher in alder. For this species, there were significant differences between sites: nitrogen content was lowest at site $\mathrm{C}$, medium at site $\mathrm{A}$ and highest at site B. In the case of eucalyptus, site B also showed significantly higher concentrations than the headwaters, but there was no difference between sites A and C.

The dynamics of phosphorus in the decaying litter differed greatly between headwater and downstream reaches (Figure 2). At sites $\mathrm{A}$ and $\mathrm{C}$, litter showed a general downward trend, which was especially clear in alder. In contrast, at site B both leaf species exhibited an increase of phosphorus content, and eucalyptus litter reached values close to initial concentrations of alder leaves. ANOVAs stressed the difference between 
Table 2. Breakdown rates $\left(\mathrm{d}^{-1}\right)$ and $95 \%$ confidence intervals of alder and eucalyptus in the studied reaches. Summary of multiple inter-site comparisons (Tukey's test) after analysis of covariance is also shown, underlining the cases where no significant differences were found

\begin{tabular}{llll}
\hline Site & Alder & Eucalyptus & Ancova \\
\hline A & $-0.0288( \pm 0.0050)$ & $-0.0097( \pm 0.0023)$ & Euc. $<$ Ald. \\
B & $-0.0321( \pm 0.0094)$ & $-0.0169( \pm 0.0053)$ & Euc. $<$ Ald. \\
C & $-0.0235( \pm 0.0055)$ & $-0.0066( \pm 0.0023)$ & Euc. $<$ Ald. \\
Inter-site & & & \\
comparisons & $\underline{\text { C A B }}$ & $\underline{\underline{C A B}}$ & \\
\hline
\end{tabular}

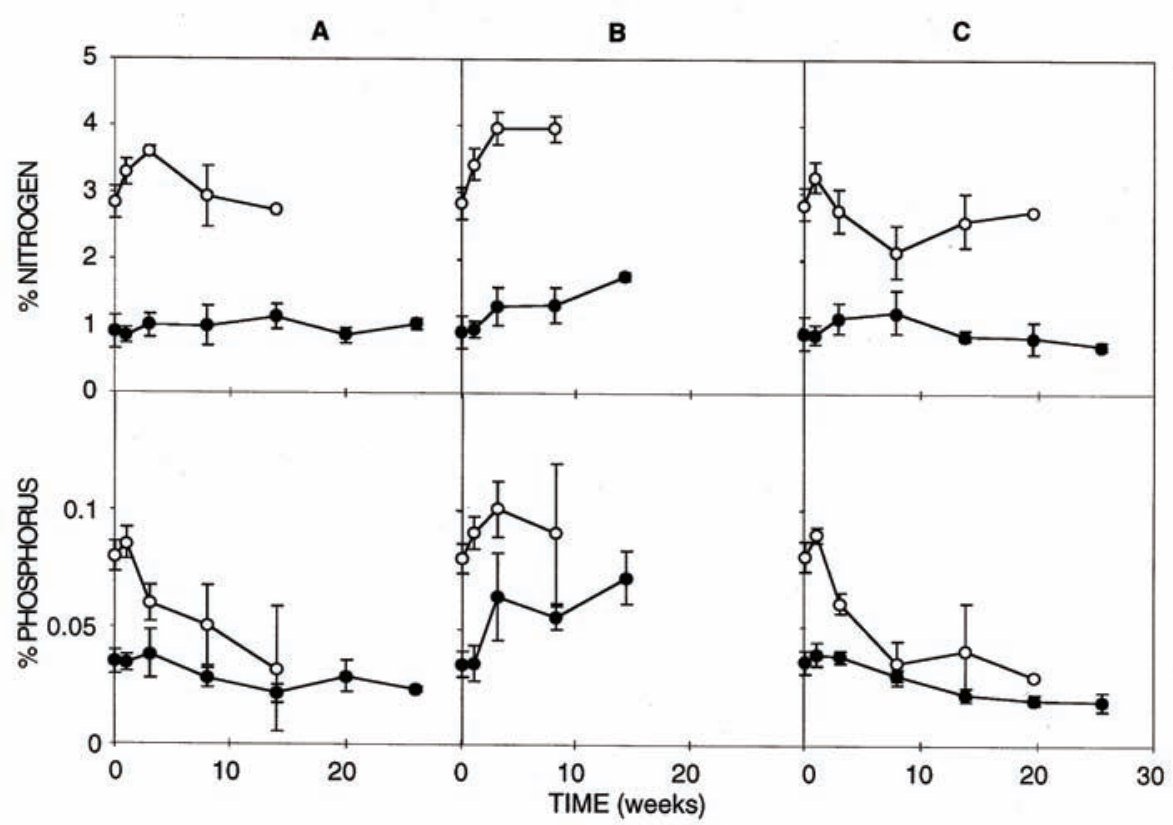

Figure 2. Nitrogen and phosphorus concentration (mean \pm S.D.) in alder $(\bigcirc)$ and eucalyptus (๑) litter.

species at all sites (Table 3), and the higher phosphorus content of litter downstream.

As a result of the variations of nitrogen and phosphorus content, the N:P ratio of litter, especially that of alder, increased in the headwaters and suffered small variations at site B (Figure 3). N:P ratio of alder was significantly higher than that of eucalyptus at all sites. Inter-site differences were only significant in the case of eucalyptus (Table 3 ).

\section{Fungal biomass}

Figure 4 shows the ergosterol content of decaying leaves. In headwaters, the general pattern of both species was very similar: although slightly different between site $\mathrm{A}$ and $\mathrm{C}$, peaks of ergosterol occurred
Table 3. Results of Tukey's tests after two way ANOVAs (time $\times$ site and time $\times$ species) for nitrogen and phosphorus contents and $\mathrm{N}: \mathrm{P}$ ratio. The cases where no significant differences were found appear underlined

\begin{tabular}{llll}
\hline Site & $\% \mathrm{~N}$ & $\% \mathrm{P}$ & $\mathrm{N}: \mathrm{P}$ \\
\hline $\mathrm{A}$ & Euc. $<$ Ald. & Euc. $<$ Ald. & Euc. $<$ Ald. \\
$\mathrm{B}$ & Euc. $<$ Ald. & Euc. $<$ Ald. & Euc. $<$ Ald. \\
$\mathrm{C}$ & Euc. $<$ Ald. & Euc. $<$ Ald. & Euc. $<$ Ald. \\
& & & \\
Species & & & \\
Alder & $\mathrm{C}<\mathrm{A}<\mathrm{B}$ & $\underline{\mathrm{C} \mathrm{A}}<\mathrm{B}$ & $\underline{\mathrm{B} \mathrm{C} \mathrm{A}}$ \\
Eucalyptus & $\underline{\mathrm{A} \mathrm{C}}<\mathrm{B}$ & $\underline{\mathrm{A} \mathrm{C}}<\mathrm{B}$ & $\mathrm{B}<\underline{\mathrm{C} \mathrm{A}}$ \\
\hline
\end{tabular}




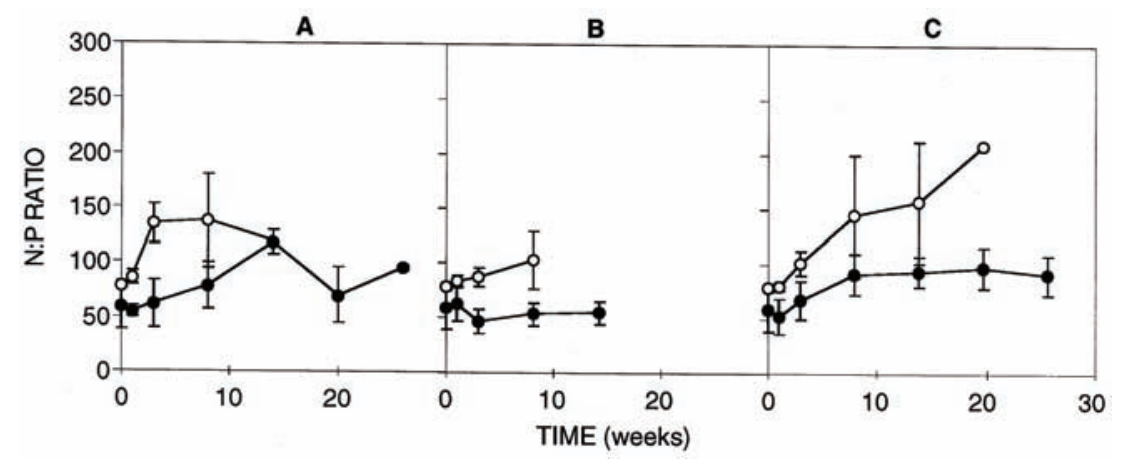

Figure 3. N/P atomic ratio (mean \pm S.D.) of alder $(\bigcirc)$ and eucalyptus ( ) litter.

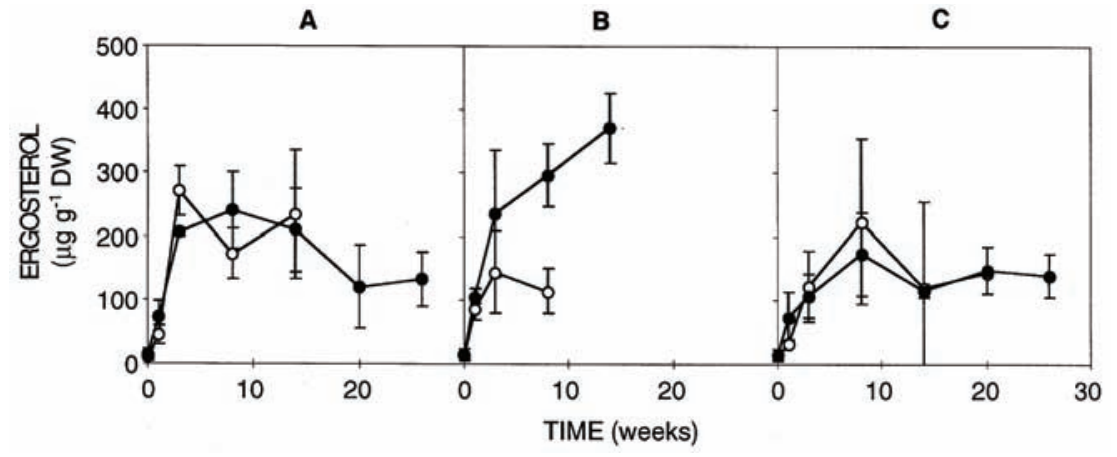

Figure 4. Ergosterol contents (mean \pm S.D.) of alder $(\bigcirc)$ and eucalyptus ( $)$ litter.

\begin{tabular}{|c|c|}
\hline \multicolumn{2}{|c|}{$\begin{array}{l}\text { Table 4. Results of } \\
\text { Tukey's tests after two } \\
\text { way ANOVAs (time } \times \text { site } \\
\text { and time } \times \text { species) for } \\
\text { ergosterol contents. The } \\
\text { cases where no significant } \\
\text { differences were found appear } \\
\text { underlined }\end{array}$} \\
\hline Site & Ergosterol \\
\hline A & Ald. Euc. \\
\hline B & Ald. $<$ Euc. \\
\hline $\mathrm{C}$ & Ald. Euc. \\
\hline \multicolumn{2}{|l|}{ Species } \\
\hline Alder & $\underline{\mathrm{B} C \mathrm{~A}}$ \\
\hline Eucalyptus & $\mathrm{AC}<\mathrm{B}$ \\
\hline
\end{tabular}

during the first 8 weeks, then the levels decreased slowly, from 200-250 to around $150 \mu \mathrm{g} \mathrm{g}^{-1}$. At site B an alder peak was reached within 3 weeks, and mean values were always lower than $150 \mu \mathrm{g} \mathrm{g}^{-1}$. Concentrations in eucalyptus, on the other hand, continued to rise during the whole study period, reaching a maxi-
Table 5. Results of Tukey's tests after two way ANOVAs (time $\times$ site and time $\times$ species) for macroinvertebrate and shredder densities (ind $g$ AFDW -1) in the litter bags. The cases where no significant differences were found appear underlined

\begin{tabular}{lll}
\hline Site & Invertebrates & Shredders \\
\hline $\mathrm{A}$ & Euc. $<$ Ald. & Euc. $<$ Ald. \\
$\mathrm{B}$ & Euc. $<$ Ald. & Euc. $<$ Ald. \\
$\mathrm{C}$ & Euc. $<$ Ald. & Euc. $<$ Ald. \\
Species & & \\
Alder & $\underline{\mathrm{A} \mathrm{B} \mathrm{C}}$ & $\mathrm{B}<\underline{\mathrm{A} \mathrm{C}}$ \\
Eucalyptus & $\underline{\mathrm{A} \mathrm{C}}<\mathrm{B}$ & $\mathrm{B}<\underline{\mathrm{C} \mathrm{A}}$ \\
\hline
\end{tabular}

mum ergosterol concentration of $360 \mu \mathrm{g} \mathrm{g}^{-1}$ after 14 weeks. ANOVAs (Table 4) showed significant differences between species only at site B, where eucalyptus was significantly richer in ergosterol than any of the other site $\times$ leaf combinations. 


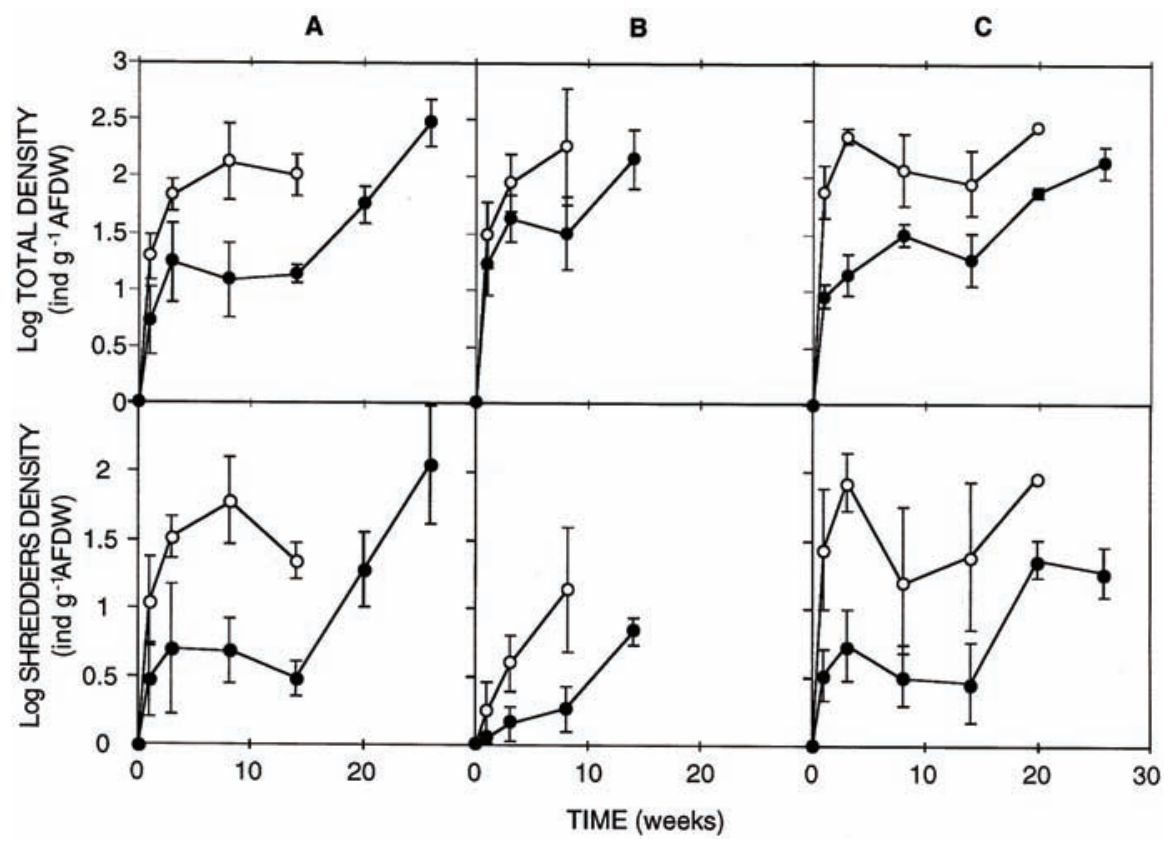

Figure 5. Log. of the number of macroinvertebrates and shredders $\mathrm{g}^{-1}$ AFDM (mean \pm S.D.) in alder $(\bigcirc)$ and eucalyptus

) litter bags.

\section{Macroinvertebrates}

The density of macroinvertebrates found in alder leaf bags rose during the first 3 or 8 weeks of colonization (depending on site), and then leveled off (Figure 5). The colonization of eucalyptus bags was slower, and the density of macroinvertebrates in this substrate continued to rise until the end of the experiment at all sites. The fauna associated with litter bags in headwaters was dominated by chironomids and shredders (e.g., Protonemura sp., Echinogammarus tarraconensis, Nemoura sp., Capnioneura sp. and Leuctra sp., at site A; Capnioneura sp., Leuctra sp. and Protonemura sp., at site C). In the mid reach, scrapers and collectors were dominant (e.g., Potamopyrgus jenkinsi, Ephemerella ignita, Baetis spp. and Simuliidae), shredders being less important (e.g., Echinogammarus berilloni and Lepidostoma hirtum). All the mentioned taxa were found in bags of both leaf species, although differences occurred in terms of density. The shredders followed dynamics quite similar to those of total macroinvertebrates, although at site B shredder density was much lower (Table 5) and the increase slower than at the headwaters (Figure 5). In all sites, the density of both macroinvertebrates and shredders on eucalyptus was significantly lower than on alder (Table 5). Although the density of macroinvertebrates on eucalyptus was significantly greater at site B than at the headwaters, shredder density was significantly lower.

\section{Discussion}

Litter breakdown is a complex process, which involves leaching, physical abrasion, microbial conditioning and processing by macroinvertebrates (Cummins et al., 1973; Cummins \& Klug, 1979; Webster \& Benfield 1986). The relative importance of these factors can change, resulting in highly variable species- and site-specific dynamics (Tuchman \& King, 1993).

The present study has not shown an effect of the type of riparian vegetation (deciduous forest versus eucalyptus plantation) on the breakdown rates of alder or eucalyptus. In contrast, Abelho \& Graça (1996) reported that, in Portugal, litter processing (eucalyptus included) was slower in streams under eucalyptus plantations than in those flowing through deciduous forests. However, these authors used fine mesh bags in their experiments compared to large mesh in the present study, which limits the comparison. Our results support previous observations from the Agüera stream (Pozo, 1993; Molinero et al., 1996), which suggested that, in this catchment, factors other than riparian vegetation influence the decomposition of several leaf species. 
Pozo (1993) reported that alder decomposed more rapidly than eucalyptus in oligotrophic headwaters, while at mid and low reaches dissolved nutrient availability allowed enhancement of conditioning and palatability of eucalyptus, thus promoting decay rates as fast as those of alder. In the present study, although the quality of eucalyptus litter at site B was enhanced, alder always decayed faster. The breakdown rate for a given species varies from year to year within the same reach (Pozo et al., 1994). In addition, the present experiment was carried out with freshly fallen leaves, instead of the dry material used in previous studies. The alder leaves used here were richer in nutrients $(2.8 \% \mathrm{~N}$ and $0.08 \% \mathrm{P})$ than the material (1.7\% N and 0.04\% P) used by Pozo (1993), while eucalyptus leaves showed only minor differences between both studies. Thus, the higher quality of alder in this study may have promoted a faster breakdown, and produced significant differences with respect to eucalyptus breakdown rates even at site $\mathrm{B}$.

While nitrogen concentration often increases as litter decays (Suberkropp et al., 1976; Tate \& Gurtz, 1986; Chauvet, 1987; Bunn, 1988a; Gessner, 1991), the pattern of change in phosphorus is less regular. Despite differences in the initial condition of leaves (fresh or dried), the nutrient dynamics of the present study are similar to those of Pozo (1993). The most interesting point is that nutrient enrichment of leaves is sitedependent. An increase of both $\mathrm{N}$ and $\mathrm{P}$ concentrations in leaves is clear only at site $\mathrm{B}$, where dissolved phosphorus concentrations were always highest. Uptake of $\mathrm{N}$ and $\mathrm{P}$ at this site was observed by Molinero et al. (1996), while release of both elements predominated in nutrient-poor water reaches, such as sites A and C. The enhancement of microbial activity on leaf material by nutrients has also been shown in other studies (Jenkins \& Suberkropp, 1995; Newell et al., 1995; Suberkropp \& Chauvet, 1995). However, this enrichment of litter does not have the same effect on the decay rate of all species: only eucalyptus, the species of lowest quality, shows enhanced decomposition at the nutrient-rich site (Molinero et al., 1996).

The increase in $\mathrm{N}$ and $\mathrm{P}$ concentrations of alder leaves at site $\mathrm{B}$ changes the litter quality, but, given its rapid mass loss, it is difficult to prove an uptake of dissolved nutrients, because we did not find increases of absolute amounts in any of both elements. However, in eucalyptus litter, the absolute amounts increased by the third week in $44 \%$ and $93 \%$, respectively. Molinero et al. (1996) have also pointed out that the relative immobilization of $\mathrm{P}$ at this site was higher than that of nitrogen. This fact was not seen neither at site $\mathrm{A}$ nor at $\mathrm{C}$, where dissolved phosphorus was clearly lower (see Table 1). Phosphorus appears to be the limiting nutrient in stream water since inorganic N:P ratios were high at all sites $(\mathrm{N}: \mathrm{P}>100)$. The higher $\mathrm{P}$ concentrations at site $\mathrm{B}$ coinciding with higher $\mathrm{P}$ immobilization in leaves (Figure 2) which resulted in lower N:P ratios (Figure 3) are consistent with this hypothesis.

The dynamics of ergosterol on decaying leaves demonstrates the importance of fungal activity (e.g., Newell, 1992; Gessner \& Chauvet, 1994; Maharning \& Bärlocher, 1996). With the exception of site $\mathrm{B}$, where ergosterol contents were higher in eucalyptus than in alder, fungal biomass showed similar dynamics in both species within a given site. Bärlocher et al. (1995) found that conidial production of fungi on E. globulus lagged 2 weeks behind alder, because of the slow leaching of phenols. The same lag was found in conidial production in our studies (Chauvet et al., 1997) but was not found for ergosterol. Peaks of ergosterol clearly occurred after those of conidial production, as has been shown for different leaf species (Maharning \& Bärlocher, 1996). Although eucalyptus litter has usually been considered as a poor quality substrate for aquatic fungi, it appears to be comparable with alder, itself one of the most readily colonized substrates in European streams (Bärlocher, 1992). The sporulation rates and specific diversity of hyphomycetes measured in our samples were similar for alder and eucalyptus (Chauvet et al., 1997), which confirms the suitability of eucalyptus as a substrate for these fungi.

The identical ranking of sites by nutrient or ergosterol contents suggests that fungi are responsible for the enrichment of eucalyptus leaves. Furthermore, the correlation between ergosterol and nitrogen or phosphorus contents at site B is significant for eucalyptus (data not shown). Thus, increased loss rate, nutrient enrichment and high concentrations of ergosterol are characteristics that differentiate eucalyptus litter breakdown between the mid reach and the headwaters.

What role do macroinvertebrates play? Our results show that alder is colonized by significantly higher densities than eucalyptus, whatever the stream. The fast breakdown of alder has often been associated with its high nutrient contents, which would make it a prime substrate for shredders (Hassage \& Harrel, 1986), even without prior microbial colonization (Gessner \& Schwoerbel, 1989; Cortes et al., 1995). Our results point also in this direction, since nutrient 
contents, total macroinvertebrate and shredder densities were usually higher in alder than in eucalyptus. Only at the end of the experiment did eucalyptus reach faunal densities similar to those previously registered by alder. This suggests that eucalyptus leaves need a conditioning period before being used by macroinvertebrates, which agrees with other reported data (e.g., Bunn, 1988b; González et al., 1998).

There is some controversy on the relative importance of microbial versus macroinvertebrate activity on litter decay. For instance, Pearson et al. (1989) reported that the importance of invertebrates in the breakdown of different litter species is highly variable: in some cases $77 \%$, but in others only $6 \%$ of the mass loss can be explained by invertebrates. Our results, and those from a previous experiment (Basaguren \& Pozo, 1994), suggest that microbial activity is responsible for the rapid decay of eucalyptus in mid reaches, where shredders have lesser importance, and water chemistry makes the nutrient enrichment of litter easier. On the other hand, selection of macroinvertebrates against eucalyptus, due to its low nutrient enrichment, could explain the slow breakdown of this species in the headwaters, where microbial activity seems to be more limited, according to ergosterol levels or conidial production (Chauvet et al., 1997).

Thus, Alnus glutinosa is a species with high nitrogen and phosphorus contents, readily colonized by shredders, that breaks down rapidly in all sites. Eucalyptus globulus, on the other hand, has lower nitrogen and phosphorus contents, is less preferred by shredders, but under high nutrient levels (particularly phosphate) can be readily colonized by fungi, thus shifting from medium to rapid breakdown rates. Although afforestation with E. globulus can produce severe changes in the timing, amount and quality of litter inputs into streams (Pozo et al., 1997), in northern Spain it has no influence on the breakdown rates of leaf species. Moreover, the factors discussed above lead us to conclude that even material as low in quality as eucalyptus leaves can be readily used when an exogenous nutrient supply facilitates microbial activity, thus reducing the potential negative impact of such afforestation practices.

\section{Acknowledgements}

This work has been supported by the research project DGICYT PB 92-0459 (General Bureau of Scientific and Technic Research, Central Government, Madrid).
Thanks to Professor David Harper (Leicester University) for improving the English style.

\section{References}

Abelho, M. \& M. A. S. Graça, 1996. Effects of eucalyptus afforestation on leaf litter dynamics and macroinvertebrate community structure of streams in Central Portugal. Hydrobiologia 324: 195-204.

Allen, S. E., H. M. Grimshaw, J. A. Parkinson \& C. Quarnby, 1974. Chemical analysis of ecological materials. Blackwell, Oxford.

Bärlocher, F., 1992. Research on aquatic hyphomycetes: historical background and overview. In F. Bärlocher (ed.), The Ecology of Aquatic Hyphomycetes. Springer Verlag, Berlin: 1-15.

Bärlocher, F., C. Canhoto \& M. A. S. Graça, 1995. Fungal colonization of alder and eucalypt leaves in two streams in central Portugal. Arch. Hydrobiol. 133: 457-470.

Basaguren, A. \& J. Pozo, 1994. Leaf litter processing of alder and eucalyptus in the Agüera stream system (Northern Spain). II. Macroinvertebrates associated. Arch. Hydrobiol. 132: 57-68.

Boulton, A. J., 1991. Eucalypt leaf decomposition in an intermittent stream in south-eastern Australia. Hydrobiologia 211: 123-136.

Bunn, S. E., 1988a. Processing of leaf litter in a northern jarrah forest stream, western Australia: I. Seasonal differences. Hydrobiologia 162: 201-210.

Bunn, S. E., 1988b. Processing of leaf litter in a northern jarrah forest stream, western Australia: II. The role of macroinvertebrates and the influence of soluble polyphenols and inorganic sediment. Hydrobiologia 162: 211-223.

Campbell, I. C., K. R. James, B. T. Hart \& A. Devereaux, 1992. Allochtonous coarse particulate organic material in forest and pasture reaches of two south-eastern Australian streams. II. Litter processing. Freshwat. Biol. 27: 353-365.

Cortes, R. M., M. A. S. Graça, J. N. Vingada \& S. Varandas de Oliveira, 1995. Stream typology and dynamics of leaf processing. Ann. Limnol. 31: 119-131.

Cummins, K. W., R. C. Petersen, F. O. Howard, J. C. Wuycheck \& V. I. Holt, 1973. The utilization of leaf litter by stream detritivores. Ecology 54: 336-345.

Cummins, K. W. \& M. J. Klug, 1979. Feeding ecology of stream invertebrates. Ann. Rev. Ecol. Syst. 10: 147-172.

Chauvet, E., 1987. Changes in the chemical composition of alder, poplar and willow leaves during decomposition in a river. Hydrobiologia 148: 35-44.

Chauvet, E., E. Fabre, A. Elósegui \& J. Pozo, 1997. The impact of eucalypt on the leaf-associated aquatic hyphomycetes in Spanish streams. Can. J. Bot., 75: 880-887.

David, J. S., M. O. Henriques, T. S. David, J. Tomé \& D. C. Ledger, 1994. Clearcutting effects on streamflow in coppiced Eucalyptus globulus stands in Portugal. J. Hydrol. 162: 143-154.

Elósegui, A., X. Arana, A. Basaguren \& J. Pozo, 1995. Selfpurification processes in a medium-sized stream. Envir. Mgmt 19: 931-939.

Gessner, M. O., 1991. Differences in processing dynamics of fresh and dried leaf litter in a stream ecosystem. Freshwat. Biol. 26: 387-398.

Gessner, M. O. \& E. Chauvet, 1994. Importance of stream microfungi in controlling breakdown rates of leaf litter. Ecology 75: 1807-1817. 
Gessner, M. O. \& J. Schwoerbel, 1989. Leaching kinetics of leaf litter with implications for the current concept of leaf processing in streams. Arch. Hydrobiol. 115: 81-90.

Gessner, M. O., M. A. Bauchrowitz \& M. Escautier, 1991. Extraction and quantification of ergosterol as a measure of fungal biomass in leaf litter. Microb. Ecol. 22: 285-291.

Golladay, S. W., J. R. Webster \& E. F. Benfield, 1989. Changes in stream benthic organic matter following watershed disturbance. Holarctic Ecol. 12: 85-96.

González, J. M., A. Basaguren \& J. Pozo, 1998. Mechanisms involved in leaf litter processing: influence of bag mesh size. In G. Bretschko \& J. Helešic (eds), Advances in River Bottom Ecology. Backhuys Publishers, Leiden: 89-97.

Graça, M. A. S., 1993. Patterns and processes in detritus-based stream systems. Limnologica 23: 107-114.

Griffith, M. B. \& S. A. Perry, 1991. Leaf pack processing in two Appalachian mountain streams draining catchments with different management histories. Hydrobiologia 220: 247-254.

Hassage, R. L. \& R. C. Harrel, 1986. Allochthonous leaves as a substrate for macrobenthos. J. Freshwat. Ecol. 3: 453-465.

ICONA, 1980. Las frondosas en el primer inventario forestal nacional. Ministerio de Agricultura. Subdirección General de Protección de la Naturaleza. Madrid.

Jenkins, C. C. \& K. Suberkropp, 1995. The influence of water chemistry on the enzymatic degradation of leaves in streams. Freshwat. Biol. 33: 245-253.

Maharning, A. R. \& F. Bärlocher, 1996. Growth and reproduction in aquatic hyphomycetes. Mycologia 88: 80-88.

Merrit, R. W. \& K. W. Cummins, 1996. An introduction to the aquatic insects of North America. 3rd. edn., Kendall/Hunt. Dubuque, Iowa.

Meyer, J. L. \& C. Jonhson, 1983. The influence of elevated nitrate concentration on rate of leaf decomposition in a stream. Freshwat. Biol. 13: 177-183.

Mitchell, A., 1988. A field guide to the trees of Britain and Europe. 2nd. ed., Collins \& Sons Ltd.

Molinero, J., J. Pozo \& E. González, 1996. Litter breakdown in streams of the Agüera catchment: influence of dissolved nutrients and land use. Freshwat. Biol. 36: 745-756.

Newell, S. Y., 1992. Estimating fungal biomass and productivity in decomposing litter. In G. C. Carroll \& D. T. Wicklow (eds), The Fungal Community. Marcel Dekker, New York.
Newell, S. Y., M. A. Moran, R. Wicks \& E. Hodson, 1995. Productivities of microbial decomposers during early stages of decomposition of leaves of a freshwater sedge. Freshwat. Biol. 34: 135-148.

Pearson, R. G., R. K. Tobin, R. E. W. Smith \& L. J. Benson, 1989. Standing crop and processing of rainforest litter in a tropical Australian stream. Arch. Hydrobiol. 115: 481-498.

Petersen, R. C. \& K. W. Cummins, 1974. Leaf processing in a woodland stream. Freshwat. Biol. 4: 343-368.

Pozo, J., 1993. Leaf litter processing of alder and eucalyptus in the Agüera stream system (North Spain). I. Chemical changes. Arch. Hydrobiol. 127: 299-317.

Pozo, J., A. Elósegui \& A. Basaguren, 1994. Aproximación sistémica al análisis de la cuenca del río Agüera. Limnetica 10: 83-91.

Pozo, J., E. González, J. R. Díez, J. Molinero \& A. Elósegui, 1997. Inputs of particulate organic matter to streams with different riparian vegetation. J. N. am. benthol. Soc. 16: 602-611.

Suberkropp, K. \& E. Chauvet, 1995. Regulation of leaf breakdown by fungi in streams: Inluence of water chemistry. Ecology 76 : 1433-1445.

Suberkropp, K., G. L. Godshalk \& M. J. Klug, 1976. Changes in the chemical composition of leaves during processing in a woodland stream. Ecology 57: 720-727.

Tate, C. M. \& M. E. Gurtz, 1986. Comparisons of mass loss, nutrients, and invertebrates associated with elm leaf litter decomposition in perennial and intermittent reaches of tallgrass prairie streams. Southw. Nat. 31: 511-520.

Tuchman, N. C. \& R. H. King, 1993. Changes in mechanisms of summer detritus processing between wooded and agricultural sites in a Michigan headwater stream. Hydrobiologia 268: $115-127$.

Vannote, R. L., G. W. Minshall, K. W. Cummins, J. R. Sedell \& C. E. Cushing, 1980. The river continuum concept. Can. J. Fish. aquat. Sci. 37: 130-137.

Webster, J. R. \& E. F. Benfield, 1986. Vascular plant breakdown in freshwater ecosystems. Ann. Rev. Ecol. Syst. 17: 567-594.

Webster, J. R., S. W. Golladay, E. F. Benfield, D. J. D’Angelo \& G. T. Peters, 1990. Effects of forest disturbance on particulate organic matter budgets of small streams. J. N. am. benthol. Soc. 9: $120-140$.

Zar, J. H., 1984. Biostatistical Analysis Prentice-Hall, Englewood Cliffs, New Jersey. 